\title{
Development of a prototype to support the lower limb during the antisepsis of open fractures
}

\author{
Desenvolvimento do protótipo para apoiar o membro inferior durante o processo de \\ antissepsia de fratura exposta \\ Desarrollo de un prototipo para apoyar el miembro inferior durante la antisepsia \\ de fractura abierta
}

Katia Cilene Ayako Inomata*; Mildred Patricia Ferreira da Costa**; Silvia Cristina Fürbringer***

\begin{abstract}
Background: The increase in the number of patients with open fractures increases the risk of bone infection. Orthopedic surgical site infections are severe complications. During the antisepsis of open fractures, trays can be turned over and spill on the surgical table and fall to the ground, increasing the risk of contamination of the surgical field and the professional's risk of falling in the wet floor.

Objectives: To develop a prototype to support the lower limb during the antiseptic preparation of open fractures.

Main topics under analysis: Informational design. Data were collected to create solutions. Two prototype models were produced in the conceptual design phase and their functionality and design were tested in manikins, providing support to the limb, allowing irrigation without splatter, adequate fluid draining and elimination, and autoclave sterilization. In the detailed design phase, the technical design was developed, and the patent was registered at the Brazilian National Institute of Industrial Property.

Conclusion: After the tests, Model 1 showed leaks and did not enable sterilization. Model 2 met the functionality and sterilization requirements.
\end{abstract}

Keywords: open fractures; perioperative nursing; surgical equipment; osteomyelitis

\section{Resumo}

Enquadramento: $\mathrm{O}$ aumento de pacientes com fratura exposta eleva o risco de infeção óssea. A infeção em sítio cirúrgico ortopédico constitui uma complicação grave. São utilizadas bandejas durante o procedimento de antissepsia da fratura exposta, passível de virar ou respingar na mesa cirúrgica e no chão, possibilitando a contaminação do campo cirúrgico e risco de queda do profissional no piso molhado.

Objetivos: Desenvolver um protótipo para apoiar o membro inferior durante o processo de antissepsia da fratura exposta.

Principais tópicos em análise: Projeto informacional. Foram levantadas informações para gerar soluções. No projeto conceitual foram construídos dois modelos de protótipos e testados em manequim, quanto à funcionalidade e design, permitindo apoio ao membro, irrigação sem respingos, destino adequado do líquido drenado e possibilitou a esterilização em autoclave. Na etapa projeto detalhado foi desenvolvido o desenho técnico e feito o registo da patente no Instituto Nacional da Propriedade Industrial. Conclusão: Após os testes, o modelo 1 apresentou vazamentos e não possibilitou a esterilização. O modelo 2 atendeu aos requisitos de funcionalidade e esterilização.

Palavras-chave: fraturas expostas; enfermagem; perioperatório; equipamento cirúrgico; osteomielite

\footnotetext{
* Msc., RN, University Center São Camilo, 09910070, São Paulo, Brazil [katia.inomata@uol.com.br]. Address for correspondence: Rua Charles Gomes de França, 243, 09910070, São Paulo, Brasil. Contribution to the article: literature search, article writing, perfoming protype test, INPI document entry. ** Ph.D., Nursing from Universyt of São Paulo. Professor, Universidade São Caetano do Sul, 01545080 São Paulo, Brasil [mildred@uol.com.br]. Contribution to the article: instructed this research for máster degree.

**** Ph.D., University of São Paulo. Member of Coren-SP câmara technical. Professor, Universidade Monte Serrat, 01535001, São Paulo [silviafur@uol.com.br]. Adress for correspondence: Rua Paulo Orozimbo, 890 Aclimação, São Paulo. Cep. 01535001, São Paulo, Brasil. Contribution to the article: co-counselor this
} research for máster degree, data analysis and discussion.

\section{Resumen}

Marco contextual: El aumento de los pacientes con fractura abierta acrecienta el riesgo de infección ósea. La infección en la cirugía ortopédica constituye una complicación grave. Durante la antisepsia de una fractura abierta se utilizan bandejas, que pueden girar o salpicar la mesa de operaciones y el suelo, lo que hace que el entorno quirúrgico se contamine y que el profesional corra el riesgo de resbalarse con el suelo mojado.

Objetivos: Desarrollar un prototipo para apoyar el miembro inferior durante la antisepsia de una fractura abierta.

Principales temas en análisis: Proyecto informativo en el que se recogió información para generar soluciones. En el diseño conceptual se construyeron y se probaron dos prototipos en un muñeco, y se observó que la funcionalidad y el diseño permiten apoyar el miembro, irrigar sin salpicar, gestionar de forma adecuada el líquido drenado y esterilizar en autoclave. En esta fase del proyecto detallado se desarrolló el diseño técnico y se registró la patente en el INPI

Conclusión: Después de realizar las pruebas, el modelo 1 tuvo fugas y no permitió la esterilización. El modelo 2 fue adecuado respecto a los requisitos de funcionalidad y esterilización..

Palabras clave: fracturas abiertas; enfermería perioperatoria; equipo quirúrgico; osteomielitis

Received for publication: 18.05 .16 Accepted for publication: 19.10 .16 


\section{Introduction}

Population growth and increased power of the means of transport have led to a greater incidence of patients with open fractures, increasing bed occupancy rates and the risk of bone infections in hospital settings (Villa et al., 2013). Surgical site infections related to orthopedic procedures are a severe and catastrophic complication for both patients and surgeons in hospitals. These infections increase the costs for hospital stays and extend the length of stay, depriving patients from their work and family life (Ercole, Chianca, Duarte, Straling, \& Carneiro, 2011).

A study on orthopedic surgical site infections conducted between 2005 and 2007 in Belo Horizonte, Brazil, reported that 63 of the 3,543 orthopedic surgery patients had surgical site infections, and 27 had osteomyelitis (Ercole et al., 2011). Bone infection is more common in patients with open fractures type III, due to the severity, size and exposure of the bone lesion at the moment of trauma (Villa et al., 2013). Thermal injuries, debris and necrotic tissue can also lead to osteomyelitis (McPherson et al., 2008).

Abundant irrigation using saline solution is one of the initial antiseptic treatments of open fractures performed in the operating room (Villa et al., 2013). Surgical instruments and equipment can be contaminated and transmit infections to patients. Preventing infection in surgical patients should be of utmost importance, and begins with cleaning, disinfection, and sterilization processes (Goss, 2012). In the surgical unit, and specifically in the operating room, during orthopedic surgeries, limb irrigation can cause splatters on the table and floor, facilitating the contamination of the surgical field and increasing the risk of fall among health professionals.

\section{Research question}

The following question was formulated taking into account the infection process of patients with open fractures, which require limb irrigation: What is the most feasible and effective antiseptic method for open fractures that prevents splatter on the surgical table and floor, thus reducing the risk of contamination of the surgical field and health professionals' risk of falling in the operating room?

The motivation for this study was the observation, during clinical practice, of splashing or splattering of fluid with blood and debris on the surgical table and floor when using the conventional technique for limb antisepsis. In addition to the risk of contamination, the wet floor of the surgical unit increases the fall risk among the professionals in the room.

The objective of this study is to develop a prototype to support the lower limb during the antisepsis of limbs with an open fracture that allows for abundant irrigation without splashing, and safe draining and elimination of the contaminated fluid. Its design should also allow for autoclave sterilization.

\section{Development}

We performed our technological research using the product development method proposed by Rozenfeld, which is divided into three phases: informational design, conceptual design, and detailed design (Rozenfeld et al., 2006).

\section{Informational design}

In the Informational Design phase, we analyzed the variables that influenced the identified problem, namely the team's difficulties in using a tray as a way of receiving the antiseptic fluid, the risk of splattering on the surgical table and floor, with no safe and adequate suction draining and elimination, and the increased fall risk among the professionals involved. One of the ways to provide safe assistance would be to design a prototype that would reduce the risk of bone infection and the professionals' risk of falling in the wet floor. After analyzing the issue, we searched for patents in the Brazilian National Institute of Industrial Property (Instituto Nacional de Propriedade Industrial, INPI) and foreign industrial property offices, using the prototype descriptions (Instituto Nacional de Propriedade Industrial, 2015). We found no objects similar to this prototype in terms of functions and features.

\section{Conceptual design}

In the Conceptual Design phase, with the purpose of solving the issue analyzed in the Informational Design phase, a model was proposed that would allow for autoclave sterilization, provide limb support, receive the antiseptic fluid, and offer adequate fluid elimination without splattering on the table and floor, as shown in Figure 1. 




Figure 1. Functional model of the prototype.

Based on the proposed model, after checking the autoclave inner dimensions and the resistance of the raw material used for manufacturing the prototype, two prototype models were manufactured and tested. As shown in Figure 2, Model 1 was made of galvanized steel, with $1.04 \mathrm{~mm}$ in thickness, $990 \mathrm{~mm}$ in length, and $189 \mathrm{~mm}$ in width. It was composed of three components with overlapping joints, and had a $5 \times 12 \mathrm{~mm}$ fluid drain hole.

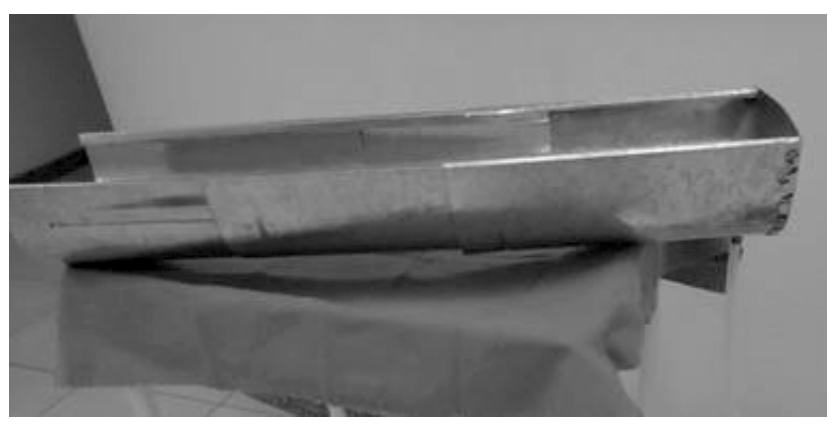

Figure 2. Prototype Model 1 for antisepsis of limbs with open fracture.

As shown in Figure 3, Model 2 was made in aluminum, with $0.30 \mathrm{~mm}$ in thickness, $860 \mathrm{~mm}$ in length, and $120 \mathrm{~mm}$ in width. It had a support bar on the right and left-hand sides, allowing the three components to extend (two $220 \mathrm{~mm}$ components and one $329 \mathrm{~mm}$ component), and a $5 \times 12 \mathrm{~mm}$ drain hole.

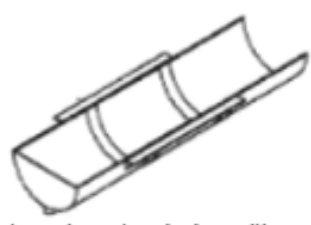

Prototype in extended poșition

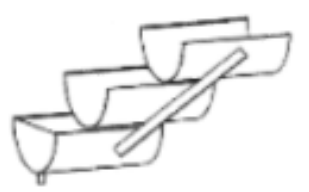

Prototype in semi-extended position

Figure 3. Prototype Model 2 for antisepsis of limbs with open fracture. Prototype in extended and semi-extended positions.

\section{Resistance and functionality test}

The tests regarding autoclave sterilization and functionality in the operating room were performed after the written authorization of the Ethics and
Research Committee of the Hospital São Bernardo. The following equipment was used to test the functionality of the prototype Models 1 and 2: latex extension, hospital suction aspirator, 3 liters of 
distilled water and methylene blue, and a white sheet placed under both prototypes and on the floor for observation of splattering or leaks.

In the functionality test, prototype Model 1 was placed on a surgical table, on top of a white sheet. A manikin leg was placed inside the prototype, the drain hole was connected to the latex extension which, in turn, was connected to the hospital suction aspirator at a vacuum pressure of $-430 \mathrm{mmh}$. Then, distilled water and methylene blue were used for irrigation.

As shown in Figure 4, we observed a leak at the junction of the prototype components (component junction is marked with letter $\mathrm{A}$, and the site where the leak occurred is marked with the letter B).

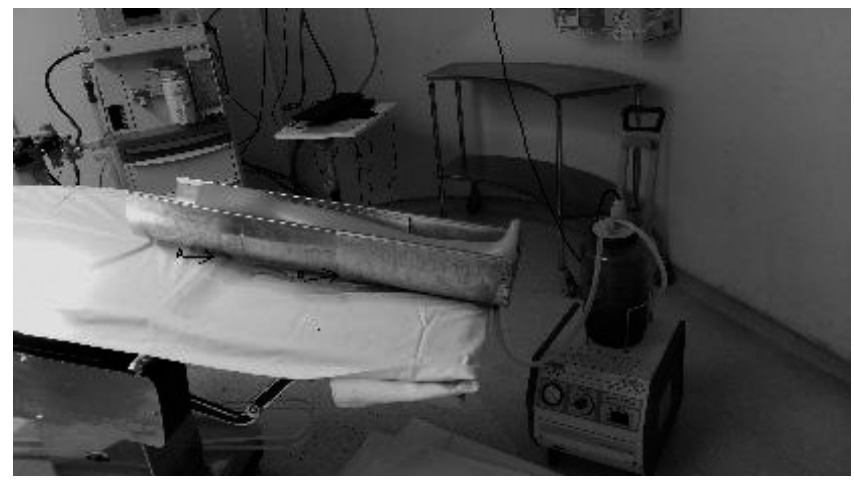

Figure 4. Prototype Model 1 with site of leakage indicated.

Model 1 could not undergo the sterilization test because its overlapping components allow the steam to circulate between them in the autoclave chamber. For the functionality test, Model 2 was placed on a surgical table, on top of a white sheet.

The drain hole was connected to a latex extension which, in turn, was connected to the hospital suction aspirator at a vacuum pressure of $-430 \mathrm{mmhg}$. An adult manikin lower limb was placed inside Model 2. The lower limb was irrigated with the methylene blue solution while the hospital suction aspirator was running.

In the functionality test, the fluid was properly drained, and there was no leakage in the components junction or splattering on the white sheet on the surgical table and floor, as shown in Figure 5.

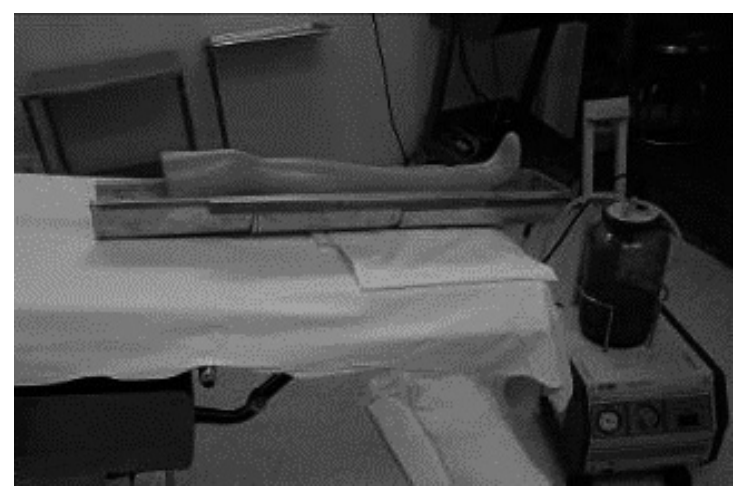

Figure 5. Prototype Model 2 placed on the surgical table, supporting the manikin lower limb, and connected to the hospital suction aspirator.

The autoclave sterilization test was performed with Model 2 in the semi-extended position. The material was prepared following the sterilization standards of the Brazilian Association of Surgical Center, Anesthetic
Recovery and Material and Sterilization Center Nurses (Sociedade Brasileira de Enfermeiros de Centro Cirúrgico, Recuperação Anestésica e Centro de Material e Esterilização, 2009). 
We obtained satisfactory results based on the data collected from the the Class 6 chemical indicator strip

1)

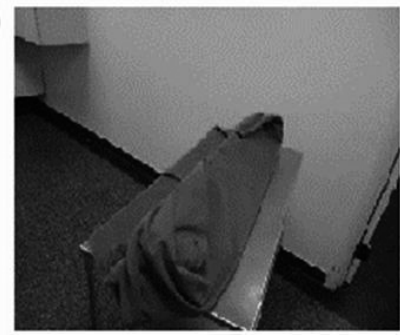

3)

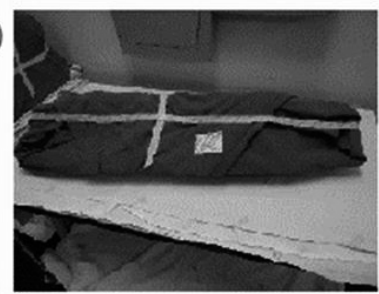

placed inside the package and the external stripe indicator tape, as shown in Figure 6.

\section{2)}

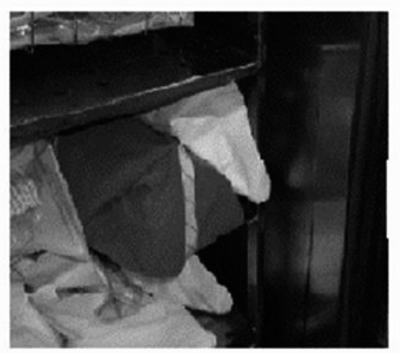

4)

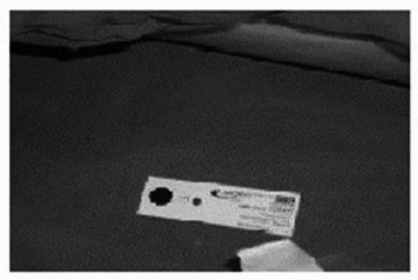

Figure 6. Prototype Model 2 preparation and sterilization test.

\section{Analysis of systems, sub-systems, and components}

After the functionality and sterilization tests, we analyzed the critical aspects of the product and decided what was the best model to be manufactured. We selected the prototype Model 2, with $950 \mathrm{~mm}$ in length and $420 \mathrm{~mm}$ in width, composed of three rounded components that would allow for a better adaptation to the limb. The length and width were based on the ABNT 15800, NBR 16060: 2012 measure reference table (Associação Brasileira de Normas Técnicas, 2012). These dimensions allow for different measures available in the market to be placed in the autoclave.

We selected polypropylene as the raw material for prototype manufacture. Its main relevant characteristics include its low cost combined with its versatility and high shape stability, allowing for sterilization at up to $220^{\circ} \mathrm{C}$, being, therefore, compatible with the autoclave technique (Araújo, 2010). Its manufacturing process includes injection molding or vacuum thermoforming, machining (turning, drilling) and connection piece (Groover, 2012).

\section{Detailed design}

In the Detailed Design phase, the technical design was elaborated, as shown in Figure 7. Letter A indicates the direction of the drained fluid, letter $\mathrm{B}$ indicates the position in which the product should be sterilized, and letter $\mathrm{C}$ indicates that the components should be pulled back to return to the limb support position. The patent is registered in National Institute of Industrial Property with the number BR 1020150327960 (Instituto Nacional da Propriedade Industrial, 2015). 

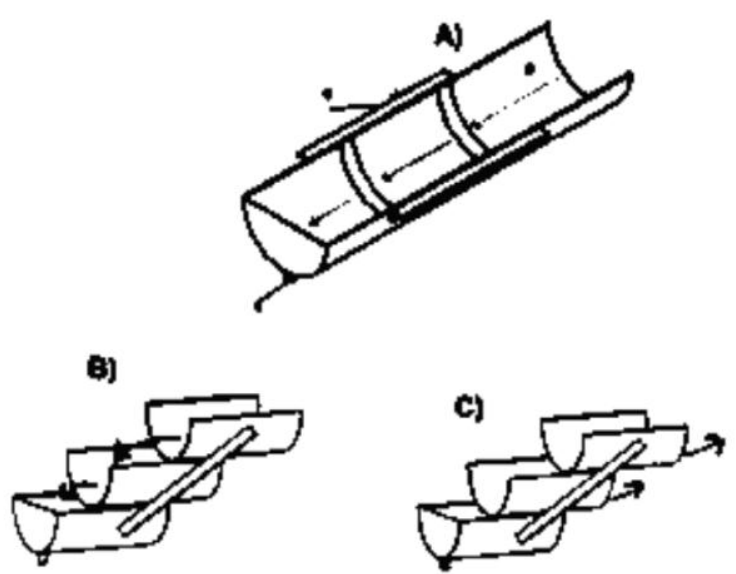

Figure 7. Technical design of the prototype for antisepsis of lower limbs with open fracture.

\section{Conclusion}

This study allowed for the manufacture of the limb support prototype for the antisepsis of limbs with open fracture. Prototype Model 1 will not be further explored because it failed the functionality test; its design did not meet the requirements for irrigation without splatter, and it was not suitable for sterilization.

Prototype Model 2 showed the desired functionality through the simulation of irrigation and antisepsis. The procedure was performed without splatter on the surgical table and floor, and with adequate fluid draining. Its design allowed for autoclave sterilization. Polypropylene was selected as the raw material. This model was registered at INPI as an invention model. We intend to perform the clinical validation of prototype Model 2 in order to identify possible improvements in the product's design and performance. Model 2 can be used in other settings other than surgical centers; it may be tested in emergency departments or inpatient units for limb support when there is a need for bandages or sutures.

\section{References}

Araújo, J. F. (2010). Estudo de propriedades mecânicas do polipropileno moldado por injeção em insertos de resinas. Curitiba, Brasil: Universidade Federal do Paraná.

Associação Brasileira de Normas Técnicas. (2012) Vestuário referenciais de medidas do corpo bumano. Rio de Janeiro, Brasil: ABNT.
Ercole, F. F., Chianca, T. C. M., Duarte, D., Starling, C. E. F., \& Carneiro, M. (2011) Risco para infecção de sítio cirúrgico em pacientes submetidos a cirurgias ortopédicas. Revista latinoamericana de enfermagem, 19(6), 269-276.

Groover, M. P. (2012). Introdução aos processos de fabricação. Rio de Janeiro, Brasil: Ltc.

Goss, L. K. (2012). Staying up to date on disinfection and sterilization techniques: Brush up on AORN's recommendations for perioperative practice. Plastic Surgical Nursing, 32(3), 112-6.

Instituto Nacional da Propriedade Industrial. (2015). Busca de patentes. Retrieved from http://www.inpi.gov.br/pedidosem-etapas/faca-busca.

McPherson, J. C., Runner, R. R., Shapiro, B. W., Walsh, D. S., Valle, J. S. \& Buxton, T. B. (2008). An acute osteomyelitis model in traumatized rat tibiae involving sand as a foreign body, thermal injury, and microbial contamination. Comparative Medicine, 58(4), 369-374.

Rozenfeld, H., Forcellini, F. A., Amaral, D. C., Toledo, J. C., Silva, S. L., Alliprandini, D. H., \& Scalice, R. K. (2006). Gestão de desenvolvimento de produtos. São Paulo, Brasil: Saraiva.

Sociedade Brasileira de Enfermeiros de Centro Cirúrgico, Recuperação Anestésica e Centro de Material e Esterilização. (2009). Práticas recomendadas (5a.ed.). São Paulo, Brasil: SOBEC.

Villa, P. E., Nunes, T. R., Gonçalves, F. P., Martins, J. S., Lemos, G. S., \& Moraes, F. B. (2013). Avaliação clínica de pacientes com osteomielite crônica após fraturas expostas tratados no Hospital de Urgências de Goiânia, Goiás. Revista Brasileira Ortopedica, 48(1), 22-28. 